\title{
Comparative Approaches to Liability for Medical Maloccurrences
}

Medical litigation, in recent years, has been characterized by impressively large recoveries in several highly publicized medical malpractice suits $^{1}$ and an apparent expansion in the scope of liability applicable to health care providers. ${ }^{2}$ In Helling $v$. Carey, ${ }^{3}$ for example, the Washington Supreme Court disregarded unanimous expert medical testimony and a jury verdict in favor of the defendant physicians to hold two ophthalmologists negligent as a matter of law for failure to give the plaintiff a pressure test designed to detect glaucoma. The test was not normally given to patients like the plaintiff who were under 40 years of age, because of the very low incidence of glaucoma within that class. Failure to detect the disease at an early stage resulted in severe damage to her visual field for which the court ordered compensation.

From the patient's point of view, larger and more accessible recoveries might seem a highly beneficial development; the malpractice liability system is meant to police the quality of care that patients receive and to compensate the victim when care is negligent. ${ }^{4}$ But on a broader view the trend is not an unmixed blessing. Malpractice litigation is typically lengthy, complex, and expensive, even for a successful plaintiff." The recent rash of suits has driven physicians' costs for malpractice insurance rapidly higher. ${ }^{6}$ In some parts of the country

1. See, e.g., TIME, Mar. 24, 1975, at 62 (recoveries of $\$ 4,025,000 ; \$ 300,000$; and $\$ 1,000,000)$; NewsweEk, Feb. 10, 1975, at 41; New Haven Reg., Feb. 15, 1975, at 35, col. 6. The concern over possibly deficient medical care is not new. See, e.g., 2 Kings 5:1-19, discussed in Gordis, An Early Commentary on Medical Care, 292 New ENG. J. MEd. 44 (1975).

2. See, e.g., Cal. Assembly Select Comm. on Medical Malpractice, Preliminary RePORT 27-32 (1974) [hereinafter cited as PRELIMINARY REPORT].

3. 83 Wash. 2d 514, 519 P.2d 981 (1974), rev'g 8 Wash. App. 1005 (1972) (copy of middle level opinion on file with the Yale Law Journal).

4. See, e.g., D. Harney, Medical Malpractice 92 (1973).

5. Malpractice litigation costs the nation an estimated two billion dollars yearly in legal fees. Welch, PSRO's-Pros and Cons, 290 New ENG. J. MEd. 1319, 1321 (1974). Indeed, Gerald Rosenthal, Director of Health Services Research, HEW, has stated that malpractice litigation may now be costing five to six billion dollars. Telephone Interview with G. Rosenthal, Jan. 29, 1975 (notes on file with the Yale Law Journal). Leading plaintiff's attorneys have asserted that only one in ten possible claims against health care providers brought to the lawyer's office will result in legal action. Rubsamen, No-Fault Liability for Adverse Medical Results-Is It a Reasonable Alternative to the Present Tort System?, CAL. MED., July 1972, at 78, 79. There is evidence that plaintiffs with claims under $\$ 20,000$ in value cannot find attorneys willing to pursue their case. Id. at 87 .

6. The volume of malpractice litigation against health care providers has increased enormously. See Project, The Medical Malpractice Threat: A Study of Defensive Medicine, 1971 Duke L.J. 939, 940 n.4. This has prompted widespread public concern. See, e.g., Suing 
insurers are threatening to withdraw coverage altogether; ${ }^{7}$ any such region is likely to have difficulty attracting new physicians. ${ }^{8}$ Perhaps more important, the threat of malpractice suits is thought by some to induce "defensive medicine"-a pejorative label for unnecessary treatment or testing given solely to avoid the possibility of a lawsuit. ${ }^{9}$ All this may mean increasing costs for the consumers of medical care, costs which possibly should be avoided.

Because the negligence liability system in the medical care field is haphazard and expensive, numerous suggestions for change have appeared. One group of proposals urges implementation of strict liability, ${ }^{10}$ a liability system which in some settings promises a substan-

the Doctor, Tme, July 15, 1974, at 78; Preniminary Report, supra note 2; Malpractice Costs Driving Doctors Off, N.Y. Times, Oct. 5, 1974, at 12, col. 3.

The dramatic rise in claims filed against providers has been accompanied by large increases in premiums paid for malpractice insurance. For example, California has witnessed a 500 percent increase in recent years. Preliminary REPORT, supra note 2, at 37. Rate increases in Connecticut ranged from 36 percent to 167 percent in the past year. Letter from M. David Deren to Physician Members in the CSMS-Aetna Professional Liability Program, undated (copy on file with the Yale Law Journal). Michigan is also experiencing difficulties with insurance availability. See, e.g., Grand Rapids Press, Nov. 28,1974 , at 1 , col. 5 .

Signs of the malaise in malpractice insurance market include the fact that "[h]ospital associations in six Midwestern states are studying the possibility of teaming with Lloyds of London in a medical malpractice insurance pool." Des Moines Reg., Jan. 1, 1975, at 3, col. 6. This move was prompted by the cancellation of policies by a California insurer. The hospital associations would create a pool to pay judgments up to $\$ 300,000$ and Lloyds of London would cover judgments in excess of this amount. With respect to New York, see Hospital Insurer Raising Rate 189\%, N.Y. Times, Mar. 5, 1975, at 39, col. 1. Asserting that doctors have become virtually uninsurable, St. Paul Fire and Marine Insurance Co. has decided to cease offering traditional insurance coverage to 48,000 doctors in 47 states. The company will no longer attempt to predict in advance claims based on medical services rendered when the policy is in effect. Rather, the company will adopt a "pay as you go" type of coverage which will cover claims reported during the year the policy is in effect. N.Y. Times, Jan. 24, 1975, at 35, col. 1. See Elser, "Claims Made"-Miracle Drug for Malpractice Insurance Market?, 16 FOR THE DEFENSE 25 (1975).

7. See Wall St. J., Dec. 30, 1974, at 10, col. 4; N.Y. Times, Jan. 12, 1975, § 5, at 6, col. 2 (New York experience); PARADE, Feb. 16, 1975, at 8. The Secretary of Health, Education and Welfare, Caspar Weinberger, has indicated that physicians in seven states are in danger of losing their malpractice coverage. Wall St. J., supra. The crisis in Maryland is detailed in Am. Med. News, Jan. 6, 1975, at 9, col. 1 .

8. There is evidence that physicians in New York are already finding that less than full time practice is not feasible because of malpractice insurance costs. See N.Y. Times, Jan. 13, 1975, at 29, col. 2; cf. Malpractice Costs Driving Doctors Off, supra note 6.

9. See, e.g., HEW Sec'y's Comm'N on Medical Milaractice, Rerort 14-15 (1973); King, Book Review, 1974 DuKE L.J. 1000, 1001.

10. See Ehrenzweig, Compulsory "Hospital-Accident" Insurance: A Needed First Step Toward the Displacement of Liability for "Medical Malpractice," 31 U. CHI. L. REv. 279 (1964); Franklin, Tort Liability for Hepatitis: An Analysis and a Proposal, 24 STAN. 1. REv. 439 (1972); Havighurst \& Tancredi, "Medical Adversity Insurance" $-A$ No-Fault Approach to Medical Malpractice and Quality Assurance, 51 HeALTH \& Soc'Y 125 (1973); Keeton, Compensation for Medical Accidents, 121 U. PA. L. REv. 590, 616 (1973) (rejects strict liability); O'Connell, Expanding No-Fault Beyond Auto Insurance: Some Proposals, 59 VA. L. Rev. 749 (1973); O'Connell, Extending the "No-Fault" Idea, The Public Interesi', Summer 1974, at 112; O'Connell, It's Time for No Fault of All Kinds of Injuries, 60 A.B.A.J. 1070 (1974); O'Connell, Elective No-Fault Insurance for Many Kinds of Accidents: A Proposal and an "Economic Analysis," 42 TENN. L. REv. 145, 146-47 (1974); Symposium, The Patient Injured by Medical Care: Whose Responsibility?, THE New PHYsician, Nov. 
tial savings in litigation costs. ${ }^{11}$ In fact, three of the justices who concurred in Helling advocated a limited implementation of strict liability in medical maloccurrence cases. ${ }^{12}$ Justice Tobriner of the California Supreme Court offered similar advice in 1968.13 A second suggested alternative involves increased reliance on collective decisionmaking with respect to what medical procedures are desirable. Under some versions of the second approach, health care providers would receive immunity from civil liability if they provided care in accordance with collectively determined standards. ${ }^{14}$

One important function of any tort liability system is to promote economic efficiency, to deter conduct which produces societal costs greater than its benefits. ${ }^{15}$ Different systems may be judged by how

1974, at 62, 64; Comment, Continuing the Common Law Response to the New Industrial State: The Extension of Enterprise Liability to Consumer Services, 22 U.C.L.A.L. REv. 401, 427-30 (1974); A. Holder, Medical Malpractice Law 431-34 (1975); J. O'Connell, ENDING Insult to INJURY (1975); N.Y. Times, Jan. 13, 1975, at 33, col. 1 .

Cases rejecting strict liability include Carmichael v. Reitz, 17 Cal. App. 3d 958, 95 Cal. Rptr. 381 (1971) (drug reaction); Silverhart v. Mount Zion Hosp., 20 Cal. App. 3 d 1022, 98 Cal. Rptr. 187 (1971) (broken surgical needle); Magner v. Beth Israel Hosp., 120 N.]. Super. 529, 295 A.2d 363 (1972) (plastic surgery); Magrine v. Krasnica, 94 N.J. Super. 228, 227 A.2d 539 (Co. Ct. 1967), aff'd per curiam sub nom. Magrine v. Spector, 100 N.J. Super. 223, 225-41, 241 A.2d 637, 638-47 (1968) (dissent advocated strict liability), aff'd per curiam, 53 N.I. 259,250 A.2d 129 (1969).

The possibility of strict liability for medical accidents has been noted in Preliminary REPORT, supra note 2, at 27, 60. Strict liability was disapproved in HEW SEC'Y's CoMm'N on Medical Malpractice, Report 30 (1973). A report to the Commission, however, outlined a strict liability system resembling Workmen's Compensation. See Roth \& Rosenthal, Non Fault Based Medical Injury Compensation Systems, in APpendix to REPORT 450 (HEW Sec'y's Comm'n on Medical Malpractice ed. 1973). Strict liability, sometimes called no-fault liability, does not mean liability without causation; it simply means that the plaintiff need not show that the defendant was negligent. Strict liability may be contrasted with absolute liability, the latter not requiring any causative link. See Passwaters v. General Motors Corp., 454 F.2d 1270, 1277 n.7 (8th Cir. 1972).

11. See Comment, supra note 10 , at $444-46$.

12. The Helling concurrence opted for strict liability when (i) the harm was caused by failure to give a simple, harmless procedure; (ii) the activity involved can be defined with sufficient precision to serve as an accounting unit to which to allocate costs; (iii) the doctors had more knowledge than the patient; and (iv) the existing medical standard afforded inadequate protection. Helling v. Carey, 83 Wash. $2 d$ 514, 521-22, 519 p.2d 981, 984.85 (1974).

13. Clark v. Gibbons, 66 Cal. 2d 399, 414, 426 p.2d 525, 535, 58 Cal. Rptr. 125, 135 (1967) (Tobriner, J., urged strict liability for unexplained medical maloccurrences even when it was not shown that the health care providers were negligent).

14. See pp. 1161-63 infra.

15. See Calabresi, Optimal Deterrence and Accidents: To Fleming James, Jr., 84 YALE L.J. 656 (1975). As Professor Calabresi points out, other goals are also important. Id. at $656 \mathrm{n} .1$.

For a discussion of the theoretical benchmark, a perfect market which achieves "Pareto optimality," see P. SAMUeLson, Economics 632 (9th ed. 1973). Because the perfectly competitive market leads to efficient allocation of resources, many economists have argued that resource allocation should be left to the market. Public policy would then be confined to the problem of achieving the socially optimal distribution of income by a system of taxes and subsidies. This approach is summarized in Arrow, Uncertainty and the Welfare Economics of Medical Care, 53 AM. Econ. REv. 941, 942-43 (1963). Since questions involving allocation of resources are roughly severable from questions of income distribution, this Note will concentrate on allocation, assuming that methods of taxation and subsidies are available to approach socially optimal income redistributions. 
well they reduce the sum of three separate costs: the costs of the maloccurrences themselves-primarily the harm to patients; the costs of detection and treatment-the costs of avoidance; and the costs of administering the system-most significantly, lawyer fees and court costs. ${ }^{10}$

This Note will measure the various malpractice liability systems by this standard. That is, it will concentrate on using the liability system to promote an economically efficient allocation of resources-this not because of any easy assumption that the costs and benefits which make up the health care calculus are readily monetizable. ${ }^{17}$ Rather, attention to the concerns of economic efficiency will serve as a focus for lawmakers and health care providers who are required to make decisions about optimal amounts of medical services. Determination of the optimal amount of care is a difficult task, largely due to fundamental problems in the medical care market. These problems, centered on uncertainty and lack of information, ${ }^{18}$ bedevil the operation of any system of liability for maloccurrences resulting from medical care. The Note begins with an examination of the information problem in the medical care market.

\section{Market Failure in the Medical Care Industry: Uncertainty and Information}

A basic tenet of modern economics is that under certain general conditions the market mechanism will allocate resources efficiently. ${ }^{10}$ Professor Kenneth Arrow has argued that the market for medical care fails to satisfy these competitive preconditions, and thus fails to function efficiently, because of the prevalence of uncertainty and the importance of information in the market. ${ }^{20}$

16. See G. Calabresi, The Costs of Accidents 26-28 (1970).

17. See Botta v. Brunner, 26 N.J. 82, 138 A.2d 713 (1958). For a recent discussion on valuation of pain and suffering, see Peck, Compensation for Pain: A Reappraisal in Light of New Medical Evidence, 72 MICH. L. REv. 1355 (1974). For a theoretical discussion, see Mishan, Evaluation of Life and Limb: A Theoretical Approach, 79 J. Pol. Econ. 687 (1971).

18. Arrow, supra note 15, at 947; cf. Arrow, Limited Knowledge and Economic Analysis, 64 AM. Econ. REv. 1, 8 (1974). The information with which this Note is most concerned is that "needed for decisionmaking by organizations and individuals who plan, finance, administer, provide, monitor and evaluate health services." Murnaghan, Health-Services Information Systems in the United States Today, 290 NEw ENc. J. MED. 603 (1974) (surveys current systems for the provision to decisionmakers of information on health carc); $c f$. Anderson, PSRO as Educational Process, 290 NEw ENG. I. MED. 1322 (1974).

19. Arrow, supra note 15, at 942-43. This section is drawn from Professor Arrow's analysis.

20. Id. at 947. The major competitive preconditions include: "the existence of competitive equilibrium, the marketability of all goods and services relevant to costs and utilities, and nonincreasing returns. The first two... insure that competitive equilibrium is necessarily optimal; the third insures that every optimal state is the competitive equili- 
Unlike most of those commodities which constitute a significant part of the consumer's budget, medical care is demanded unpredictably and irregularly. ${ }^{21}$ Neither the incidence of illness nor the costs of recovery from illness (including loss of earning power) can be known in advance. The likelihood that the patient will have information about the "product" and the "producer" is therefore low. This problem is compounded by the nature of the product-medical care-itself; it too consists largely of information: a diagnosis, a recommended treatment, and a prognosis. ${ }^{22}$ Moreover, the product provided by the physician is itself of highly uncertain value; no matter how skillful the physician, it is hard to know whether the diagnosis is correct and whether the treatment will be effective. ${ }^{23}$ Information thus plays a double role in the medical care industry: it is both part of the commodity bought and the means of mitigating the uncertainty surrounding the purchase. The patient cannot value what he is buying; "if, indeed, he knew enough to measure the value of information, he would know the information itself." 24 The market cannot efficiently allocate commodities which buyers cannot efficiently price.

According to Arrow, the imperfect marketability of information helps to explain the institutional characteristics of the medical care industry. ${ }^{25}$ For example, a relationship of trust has developed under

brium corresponding to some distribution of income." Id. at 944. The precondition not fulfilled is the existence of markets for all goods and services, particularly insurance. See note 25 infra.

21. Id. at 948-49.

22. Id. at 946 .

23. See Thomas, Guessing and Knowing: Reflections on the Science and Technology of Medicine, Saturday REv.-ScI., Sept. 23, 1972, at 52, 54 (remarks by Dean of Yale Med. School); Dykes, Uncritical Thinking in Medicine-The Confusion Between Hypothesis and Knnowledge, 227 J.A.M.A. 1275, 228 id. 708 (1974).

"The way a doctor decides on a plan of management for a particular situation is to review all previous clinical experience, to select those patients whose clinical situation closely resembled the one now at hand, to recall the treatments and outcomes in the 'resemblance group,' to choose the treatment that gave the most successful results, and to attempt to reproduce that success in the current patient.... [T] he conventional activities of clinical work... can quite properly be regarded as experiments." Feinstein, clinical Biostatistics-XXVI. Medical Ethics and the Architecture of Clinical Research, 15 CLIN. Pharmacol. \& Therapeutics 316, 318 (1974); cf. A. Feinstein, Clinical Judgment 21-22 (1967). See generally Francois v. Mokrohisky, No. 426 (Wis., Mar. 6, 1975) (slip opinion at 5) ("physicians too often have attempted to encourage the aurae of an infallibility they do not possess. Theirs is not an exact science and even the very best of them can be wrong in diagnosis or procedure.").

24. Arrow, supra note 15 , at 946 .

25. Id. at 947. A second factor Professor Arrow lists is nonmarketability of risk bearing. Arrow argues that "a great many risks are not covered" in the medical care industry, and "the markets for the services of risk coverage are poorly developed or nonexistent." Id. at 945. "By the absence of marketability for an action which is identifiable, technologically possible, and capable of influencing some individual's welfare, for better or worse, is meant here the failure of the existing market to provicle a means whereby the services can be both offered and demanded upon payment of a price. Nonmarketability may be due to intrinsic technological characteristics of the product which prevent a suitable price from 
which the physician is expected to act for the patient's welfare, not as a profit-maximizer supplying the product solely for his own selfinterest. ${ }^{26}$ Arrow argues further that social institutions, most prominent among them the government, will intervene in situations of market failure to attempt to achieve an efficient allocation by nonmarket means. ${ }^{27}$ One means of intervention is the medical malpractice liability system. ${ }^{28}$

\section{Negligence and Medical Malpractice}

The standard of care for health care providers has traditionally been based on a variant of negligence theory. Negligence, or fault, demands that a defendant's conduct conform to the conduct of the "reasonable man"; if it does not, the defendant must pay damages. ${ }^{20}$ Judge Learned Hand gave content to this standard in his famous calculus for negligence announced in Conway $v$. O'Brien: $:^{30}$

The degree of care demanded of a person by an occasion is the resultant of three factors: the likelihood that his conduct will injure others, taken with the seriousness of the injury if it happens and balanced against the interest which he must sacrifice to avoid the risk. All these are practically not susceptible of any quantitative estimate, and the second two are generally not so, even theoretically. For this reason a solution always involves some preference, or choice between incommensurables, and it is consigned to a jury because their decision is thought most likely to accord with commonly accepted standards, real or fancied.31

A person is liable under a fault system, then, if the cost of the harm discounted by its probability is greater than that person's cost to prevent the harm. ${ }^{32}$ Assuming perfect knowledge, ${ }^{33}$ the Hand calculus will yield an efficient allocation of resources; total costs-the sum

being enforced, as in the case of communicable diseases, or it may be due to social or historical controls, such as those prohibiting an individual from selling himself into slavery." Id.

26. Arrow, Social Responsibility and Economic Efficiency, 21 Public Policy 303, 313. 17 (1973).

27. See note 18 supra.

28. It is a familiar notion that the legal system may act as a surrogate for the market where the market itself fails. See M. FrIedman, Occupational Licensure, in Capitalism \& FREEDOM 157 (1962); cf. Arrow, supra note 26, at 310-13.

29. W. Prosser, THE HANDBOOK OF THE LAW OF TORTS $\$ 32$, at 149-66 (4th ed. 1972).

30. 111 F.2d 611 (2d Cir. 1940), rev'd on other grounds, 312 U.S. 492 (1941).

31. III F.2d at 612 .

32. See Calabresi \& Hirschoff, Toward a Test for Strict Liability in Torts, 81 YALE L.J. 1055,1057 (1972). A particular avoidance cost might mitigate several injuries. Therefore, the actual Hand calculus is somewhat more complex.

33. See G. Calabresi, supra note 16 , at 91 . 
of accident costs and accident prevention costs-will be minimized. ${ }^{34}$

A further qualification is required. If there are two parties involved in a transaction which entails various probabilities of maloccurrences, it is possible that each party's cost to avoid a maloccurrence is less than the cost of the maloccurrence discounted by its probability. The Hand negligence calculus, as previously defined, does not specify on which of these parties liability should fall. ${ }^{35}$ If one assumes, however, that the Hand formulation was designed to allocate blameworthiness on the basis of achieving an efficient allocation of resources, ${ }^{36}$ the dilemma is solved. The party who can avoid the accident at the lesser cost should be held liable. Thus, a plaintiff who is contributorily negligent should not recover against a negligent defendant if the plaintiff could have avoided the maloccurrence at less expense than the defendant. However, a contributorily negligent plaintiff should recover if the negligent defendant could have more cheaply avoided the accident. ${ }^{37}$ The Hand test, modified for contributory negligence, would optimize allocation of resources, assuming no transaction costs. Under this system of fault, the victim bears the costs of all accidents not worth avoiding. ${ }^{38}$

Some form of the Hand test thus could be applied to determine liability in cases involving medical maloccurrences. Theoretically, adjudication of liability under the test would provide health care providers with useful information, identifying those procedures for which costs exceed benefits. A functioning Hand test would in addition protect patients against the failure of their physicians to provide all health care for which benefits exceed costs.

The negligence test, however, is often modified when applied to

34. See R. POSNer, Economic Analysis of LAw 69-70 (1972); Calabresi \& Hirschoff, supra note 32, at 1057; Posner, $A$ Theory of Negligence, 1 J. LEGAL STUD. 29, 32-33 (1972).

35. See R. POSNER, supra note 34, at 70-71.

36. See id. at 69.70.

37. Calabresi \& Hirschoff, supra note 32 , at 1058 .

38. Id. at 1059. Application of the Hand calculus to Helling v. Carey, see p. 1141 supra, offers an instructive example of how the negligence test works. The likelihood of glaucoma if the pressure test was not given was established at trial as approximately 1 in 25,000. The cost of the injury was deprivation of large portions of one's visual field for the remainder of one's life. And the cost of avoiding the injury was the cost of administering the pressure test. Suppose the cost of the pressure test is $\$ 10$, and the cost of glaucoma is $\$ 200,000$. Then the discounted cost of glaucoma-the cost of the risk-is $\$ 8$. (1 in $25,000=.00004$ or .004 percent; $.00004 \times \$ 200,000=\$ 8$.) Under those circumstances, the Hand test implies that ophthalmologists would not be negligent in failing to give the pressure test.

Helling noted that the pressure test was simple. This suggests that the judges placed a low value on the cost of avoiding glaucoma. However, the judges apparently did not consider the aggregate cost of giving the test to 25,000 individuals to discover one victim of glaucoma, or else the judges simply made no effort to discount the cost of glancoma by its likelihood of occurrence. Thus, it is not clear' that the defendant ophthalmologists, or their profession, were negligent under the standard propounded by Judge Hand. 
health care providers by some variant of the defense of customary conduct. Physicians traditionally have been liable only if their conduct failed to conform to the standard of care observed by comparable practitioners in the medical professions. ${ }^{39}$ Lawmakers should not assume that the defense of custom is automatically related to the promotion of optimal health care. Customary conduct may be the result of careful analysis, but it may also "arise from the kind of inadvertence, carelessness, indifference, cost-paring and corner-cutting that normally is associated with negligence." 40 A group setting its own standard may lack incentive to make progress in the direction of safety, ${ }^{41}$ since cases would be infrequent which hold one liable for not doing something none have done before. ${ }^{42}$ The customary conduct defense thus gives the medical profession special protection from liability for outcomes which might otherwise be considered negligent results. This protection means that injured plaintiffs cannot receive compensation from their injurer for all forms of negligence; where the defense of custom is recognized, providers are not liable for customary negligence..$^{43}$ The custom defense consequently protects physicians from liability to which they would be subject under an ideal

39. In the past, the standard of care required of a physician was that of comparable physicians in the same, or similar communities. Ferrell v. Ellis, 129 Iowa $614,615,105$ N.W. 993 (1906); Alexander v. Alton Ochsner Med. Foundation, 276 So. 2d 794, 799 (La. App. 1973); Brock v. Gunter, 292 So. 2d 328, 330-31 (La. App. 1974); Raitt v. Johns Hopkins Hosp., 322 A.2d 548, 551 (Md. Spec. App. 1974); Small v. Howard, 128 Mass. 131,132 (1880); Hansen v. Pock, 57 Mont. 51, 58-59, 187 P. 282, 284 (1920); some states now disregard the practice in a local community, preferring to apply a wider standard of care. Sinz v. Owens, 33 Cal. 2d 749, 754, 205 P.2d 3, 5-6 (1949); Gist v. French, 136 Cal. App. 2d 247, 269-71, 288 P.2d 1003, $1017-18$ (1955); Pederson v. Dumouchel, 72 Wash. 2d 73, 79, 431 P.2d 973, 978 (1967); A. Holder, supra note 10, at 53-55. This is especially true as regards specialists. E.g., McGulpin v. Bessmer, 241 Iowa $1119,1129-32$, 43 N.W.2d 12I, 126 (1950); Brune v. Belinkoff, 354 Mass. 102, 235 N.E.2d 793 (1968); A. HoLder, supra note 10 , at 55-57.

The strict locality rule proved an unsatisfactory guide for determining the appropriateness of a provider's conduct for two reasons. First, community professionals were reluctant to testify about the local standard of care. Second, the possibility remained that a small group of providers could establish an unsatisfactory local standard of care through laxity or carelessness. Pederson v. Dumouchel, 72 Wash. $2 d$ 73, 77-78, 431 P.2d 973, 977 (1967). The plaintiff has usually been required to elicit expert testimony establishing the applicable standard of care. See Raitt v. Johns Hopkins Hosp., 322 A.2d 548, 550-51 (MId. Spec. App. 1974); Francois v. Mokrohisky, No. 426 (Wis., Mar. 6, 1975).

Both the requirement of expert testimony and the necessity to establish the applicable professional standard of care are being abandoned by some courts with respect to informed consent. See, e.g., Miller v. Kennedy, 522 P.2d 852, 859 (Wash. App. 1974); Holland v. Sisters of St. Joseph of Peace, 522 P.2d 208 (Ore. 1974); Holt v. Nelson, 523 P.2d 211, 215 n.l (Wash. App. 1974); Note, Informed Consent and the Dying Patient, 83 Yale L.J. 1632,1639 n.44 (1974) (collects cases).

40. W. Prosser, supra note $29, \S 33$, at 167 .

41. See Pederson v. Dumouchel, 72 Wash. 2d 73, 78, 431 P.2d 973, 977 (1967); Posner, supra note 34 , at 39 ; R. POSNER, supra note 34 , at $71-72$.

42. See W. Prosser, supra note $29, \$ 33$, at 167 .

43. See Pederson v. Dumouchel, 72 Wash. 2d 73, 78, 431 P.2d 973, 977 (1967); cf. Hiatt v. Groce, 523 P.2d 320 (Kan, 1974). 
Learned Hand test. In recent years a few courts, including the Washington Supreme Court in Helling, have pierced the custom defense, ${ }^{44}$ making their own assessments of relative costs and benefits for a given procedure. This development is generally a desirable one, offering a means of policing against customary negligence.

Application of the Hand test in the context of medical maloccurrences, however, may be an ideal impossible to attain. The uncertainty of the medical care market means that the jury's role of comparing incommensurables is even more difficult in medical malpractice cases than in most other tort lawsuits. The custom defense therefore may represent less distortion, on the whole, of the Hand calculus than the present system of jury discretion as to damages. ${ }^{45}$ An important reason for the retention of the custom defense has been the fear that juries might abuse their power by too frequently compensating the injured party, ${ }^{40}$ awarding damages even when the cost of avoiding the maloccurrence is greater than the discounted cost of the maloccurrence. A systematic bias of juries in this direction could result in a misallocation of resources, one which might be greater than the misallocation resulting from the custom defense. This misallocation would

44. Some courts have qualified the professional standard rule with the caveat that due regard be given to the advanced state of the profession, suggesting that physicians must keep reasonably abreast of developments. Incollingo v. Ewing, $444 \mathrm{~Pa}$. 263, $282 \mathrm{A.2d} 206$ (1971); Darling v. Charleston Comm'y Mem. Hosp., 33 Ill. 2d 326, 211 N.E.2d 253 (1965); Hernandez v. Clinical Pasteur, Inc., 293 So. 2d 747, 749 (Fla. App. 1974); cf. Lundahl v. Rockford Mem. Hosp. Ass'n, 93 Ill. App. 2d 461, 465, 235 N.E.2d 671, 674 (1968); Favalora v. Aetna Cas. \& Sur. Co., 144 So. 2d 544, 550-52 (La. App. 1962) (expert testimony established standard practice, but also that profession recognized such practice as negligent; therefore, custom held not a defense). Helling $v$. Carey ignored unanimous testimony establishing the standard of care of ophthalmologists, to which the defendant physicians had conformed. The decision suggests that medical malpractice may be turning to straight negligence theory without the custom defense perturbation. Helling v. Carey, 83 Wash. 2d 514, 591 P.2d 981 (1974), citing Texas \& Pac. Ry. v. Behymer, 189 U.S. 468, 470 (1903) (Holmes, $\mathrm{J}$ ) (custom is evidence of the standard of care but not determinative) and The T.J. Hooper, 60 F.2d 737, 740 (2d Cir. 1932) (L. Hand, J.) ("a whole calling may have unduly lagged in the adoption of new and available devices").

One commentator has termed Helling an "audacious pronouncement," adding that "[t]he casualty insurance companies and defense counsel all around the country have been stunned by this decision." Curran, Glaucoma and Streptococcal Pharyngitis: Diagnostic Practices and Malpractice Liability, 291 NEw ENG. J. MED. 508 (1974). See Stieglitz, Liability of Accountants and Investment Counselors, 15 FOR THE DEFENSE 92 (1974) "The shock waves from the decision in Helling $v$. Carey [footnote omitted] have already begun to spread and may be expected to permeate all areas of professional negligence litigation in time"); cf. No-Fault Malpractice Insurance, 292 NEw ENG. J. MED. 163 (1975) (letters regarding Curran, supra). Another approach to weakening the defense of customary professional conduct is to broaden the class of experts allowed to testify to the standard. See, e.g., Hiatt v. Groce, 523 P.2d 320 (Kan. 1974) (mother of 16 children allowed to testify contrary to unanimous testimony of health care providers as to the applicable standard of care for the delivery of infants).

45. See, e.g., Botta v. Brunner, 26 N.J. 82, 138 A.2d 713 (1958).

46. See Nixon, Changing Rules of Liability in Automobile Accident Litigation, 3 LAw \&. Contemp. Prob. 476 (1936). 
result if health care providers complied with the standard of conduct established by the jury determination. ${ }^{47}$

The custom defense, despite its drawbacks, may therefore be seen as the closest approximation to the Learned Hand test we have available for some difficult cases. Experts-preferably doctors representing the profession as a whole and not simply local practitioners ${ }^{48}$-would in effect be weighing the Hand test's incommensurables in this highly uncertain area, rather than lay jurors. ${ }^{43}$ The danger of enshrining negligent practices, however, suggests the need to validate any customary conduct defense by systematic cost-benefit analysis, if lawmakers decide not to abandon the defense altogether.

\section{Restructuring the Negligence Liability Framework}

Departures from traditional approaches might provide greater assurance that the cost-benefit analysis (which a determination of negligence liability theoretically approximates) is carried out with reasonable accuracy at low administrative cost. Lawmakers might opt for strict liability, ${ }^{50}$ which would remove the necessity for a jury neg-

47. Jury bias in favor of plaintiffs would not necessarily adversely affect resource allocation. Defendants might still weigh the costs and benefits of risky actions and opt to pay damages if the damages are still cheaper than accident avoidance. Misallocation would occur, however, if defendants-in this case health care providers-viewed juries as actually making the determination of what constitutes optimal accident avoidance. Providers especially would rely on jury determinations if the health care defendants feared personal liability for damages due to inadequate insurance, or if they feared the stigma of being branded negligent.

48. See note 39 supra.

49. Courts could modify the custom defense by viewing customary conduct as evidence of the proper standard of care, and not dispositive. See Helling v. Carey, 83 Wash. 2d 514,519 P.2d 981 (1974). A rule which permits introduction of evidence on the advanced state of the profession, in a sense making the custom defense rebuttable upon a showing that practitioners are lagging behind in the acquisition of new knowledge, might be another possible intermediate step. This rule would return the law to its status in earlier cases like Hansen v. Pock, 57 Mont. 51, 58-59, 187 P. 282, 284 (1920). See sources cited in note 44 supra.

The pressure caused by negligence claims has prompted some tentative steps toward self-regulation and systematic study within the profession. The Connecticut State Medical Society and Aetna Life \& Casualty have established four claims review panels in Connecticut. The panels, convened by legal counsel for the insurance company, represent a cooperative effort between the sued physician, his peers, and the insurer and its lawyers. The patient's counsel is not present when the panel hears a claim. The participants hope to develop case histories out of the program to use as examples in a continuing educational program among physicians to hold down the amount of malpractice. Interview with Leonard Tomat, Connecticut State Medical Society (CSMS), in New Haven, Conn., Jan. 16, 1975 (notes on file with the Yale Law Journal). "The claims review panels have proven to be a most worthwhile educational experience and have involved more than 100 physicians in case evaluations which have in turn resulted in more equitable and more prompt settlements. It is Aetna's opinion, that without these claims review panels the rate increase in Connecticut might well have been higher." Letter from $M$. David Deren, supra note 6.

50. Some physicians have expressed interest in "no-fault" liability. See, e.g., Rosenberg, No-Fault Malpractice Insurance, 292 NEw ENG. J. MED. 163 (1975); N.Y. Times, Jan. 
ligence verdict. Alternatively, lawmakers might select a system of collective deterrence, ${ }^{51}$ in which some centralized decisionmaker either advises the jury as to what conduct results in benefits greater than costs, or decides the outcome without a jury. Finally, lawmakers could adopt an eclectic system involving elements of traditional negligence, strict liability and collective deterrence.

\section{A. Strict Liability as an Alternative}

A strict liability system would impose liability on health care providers, without regard to negligence, for maloccurrences which are related to medical intervention or nonintervention. Little work has been done toward formulating a general theory of strict liability. ${ }^{52} \mathrm{~A}$ notable exception is the test for strict liability proposed by Professors Calabresi and Hirschoff. ${ }^{53}$ They have argued that the Hand negligence test is falling into disfavor, because it is interventionistic, calling for an organ of the state to decide if an action is worthwhile; ${ }^{54}$ because it is administratively expensive; ${ }^{\tilde{5}}$ and because it is a clumsy way to deter in a world where risks are commonly insured. ${ }^{.6}$ That is, fault is determined as between the immediate parties to the particular maloccurrence, but costs are often not borne at that level.57

As an alternative, Calabresi and Hirschoff propose that strict liability for accidents be imposed on whichever "of the parties to the accident is in the best possible position to make the cost-benefit analysis between accident costs and accident avoidance costs and to act on that decision once it is made." 58 According to its originators, this test

13,1975 , at 33, col. 2. However, physicians probably do not mean strict liability-"literal no-fault"-when they refer to no-fault liability. Rather, physicians refer to a workmen's compensation-type system, or some form of liability which does not label the physician as negligent. G. Parrella, Medical Malpractice Insurance (remarks to the Conn. Med. Soc'v House of Delegates, Nov. 20, 1974; copy on file with the Yale Law Journal).

51. Collective, or specific, deterrence refers to collective decisionmaking regarding how much of an activity to permit and how an activity should be performed. For a discussion of this approach, see G. CALABRESI, supra note 16, at 95-129.

52. Kalven, Tort Law-Tort Watch, 34 AM. TRIAL LAw. J. 1, 31 (1972).

53. Calabresi \& Hirschoff, supra note 32. The authors of the test have never discussed application of strict liability to medical maloccurrences.

54. See id. at 1074. For a discussion of a "reverse Learned Hand test," which would put the burden of all accidents not worth avoiding on the injurer rather than on the victim, see $i d$. at 1059 . Professor Calabresi gives a more detailed account of the reverse Hand test in Calabresi, supra note 15, at 664.66.

55. See Calabresi \&: Hirschoff, supra note 32, at 1075-76.

56. See id. at 1069-70. Professor Calabresi has presented a concise assault on the fault system in Calabresi, supra note 15 , at $657-64$.

57. See Calabresi \& Hirschoff, supra note 32, at 1075.

58. Id. at 1060 (emphasis deleted). 
would be applied to broad categories, and not to individuals on a caseby-case basis. It would not entail government intervention to determine which party is at fault. ${ }^{59}$ Implicit in the test is the notion that strict liability should replace fault wherever a marked differential in ability to perform the cost-benefit analysis relevant to the maloccurrence is evident between identifiable categories of parties.

The Calabresi-Hirschoff strict liability test and the Hand negligence test differ in three important ways. First, the Calabresi-Hirschoff test emphasizes that some individuals have more information than others, and it gives explicit recognition to transaction costs. These concerns are at best only implicit in the Hand test. Second, the Calabresi-Hirschoff strict liability test places liability for a maloccurrence on the cheapest cost avoider even when the maloccurrence is not worth avoiding. In contrast, the Hand negligence test would place liability for accidents not worth avoiding on the victim. ${ }^{60}$ Third, the strict liability test simply asks who is the best decisionmaker, not what decision should be made-the question asked in a determination of fault under a negligence system.

A superficial application of the test to the medical maloccurrence field suggests that the physicians should be strictly liable. Presumably health care providers, as a category, have more information or better access to information than their patients and are therefore in a better position to perform the cost-benefit analysis as to what procedures to follow in diagnosing and treating ailments. Moreover, strict liability seems to promise a savings in administrative costs comparable to that expected under no-fault automobile insurance plans or under strict products liability. ${ }^{61}$ There are several reasons, however, for lawmakers to doubt the efficacy of strict liability when applied to medical maloccurrences.

59. Intervention would still be required to ascertain which category represents the party best able to make the cost-benefit analysis and carry it out, but this is significantly less government involvement than in the negligence test, in which a "government agency" (the jury) actually does the cost-benefit analysis.

60. Professor Posner, opposed to strict liability in general, has argued that the Calabresi-Hirschoff test simply requires a determination of which party is in a better position to minimize the costs in a risky interaction, which is basically the same analysis required by negligence theory. Posner, Strict Liability: A Comment, 2 J. LEGAL STUD. 205, 213-15 (1973). Professor Calabresi has given a partial response. See Calabresi, supra note 15, at 666-67.

61. Compare Bombaugh, The Department of Transportation's Auto Insurance Study and Auto Accident Compensation Reform, 71 Colum. L. REv. 207, 229-31 (1971) (collects data on administrative costs of negligence system) with Comment, supra note 10, at 444-46. Personal liability insurance premiums have decreased more than expected under New York's no-fault auto insurance system. N.Y. Times, Feb. 21, 1975, at 1, col. 2. 


\section{Defining Compensable Events}

The key difficulty lies in defining compensable events, ${ }^{02}$ a problem analogous to, but far more knotty than, defining "defect" in products liability cases. ${ }^{63}$ Many patients will suffer permanent impairmentor death-despite the physician's best efforts. To make the physician responsible for maloccurrences, regardless of whether they were iatrogenic (therapy-induced), would convert the physician into a general health insurer for all his potential patients, except perhaps those stricken so suddenly that they die before reaching the doctor's office. Plainly strict liability must be limited to iatrogenic maloccurrences, but isolating those events from all maloccurrences will be difficult, easily controverted, and probably much litigated. For this reason, administrative costs may remain nearly as high as they are under a fault system. ${ }^{64}$

For example, suppose alternative treatments for a patient's ailment are available. If the patient can prove at trial that he would be better off had he been given the other treatment, then strict liability treats the differential in well-being as iatrogenic and compensable. Or suppose a patient has surgery on an arm mangled in an auto accident. The blood supply to the arm is deficient and gangrene develops. The court or jury must then determine whether the surgery or the auto accident caused the gangrene. Finally, assume a situation like Helling v. Carey where an impairment can be traced to failure to use a certain diagnostic test. The physician had control, in that instance, of the selection of the test, and was in the best position to make the analysis of costs and benefits involved in using the test for patients under 40 . Under the Calabresi-Hirschoff test, the physician should be held liable. But suppose the physician could detect and then prevent a malady only by giving a recently discovered $\$ 10,000$ test, available only at one distant hospital. Should he still be liable, even if the malady only "costs" the patient $\$ 100$ ? At what point does the difficulty of diagnosis become so great that the physician no longer is the cause, for purposes of strict liability, of the ailment?

The problem can be overcome, to some extent, by adopting a much

62. This difficulty has been recognized. See, e.g., O'Connell, Expanding No-Fault Beyond Auto Insurance: Some Proposals, 59 VA. L. REV. 749, 790-93 (1973), citing Keeton, Compensation for Medical Accidents, 121 U. PA. L. REv. 590, 614-15 (1973). But cf. Comment, supra note 10 , at $424-30$.

63. See generally Fischer, Products Liability-The Meaning of Defect, 39 Mo. L. REv. 339 (1974), discussing Restatement of TORTs 20 \$ 402A; Comment, Products Liability: Is $\$ 102 \mathrm{~A}$ Strict Liability Really Strict in Kentucky?, $62 \mathrm{KY}$. L.J. 866 (1974).

64. See Posner, supra note 60, at 209. 
less ambitious strict liability system. The application of strict liability might extend only to certain narrowly defined events which are clearly iatrogenic, a limitation which could achieve some reductions in administrative costs. ${ }^{65}$ The remaining maloccurrences resulting in claims against physicians, however, would continue to be handled under the traditional negligence framework.

\section{Malpractice Insurers and Administrative Costs}

Malpractice insurers and lawyers play an important and remunerative $^{66}$ role in the present negligence system. The difficulties in determining iatrogenicity under strict liability may sustain administrative expenses caused by these parties at a level comparable to that now plaguing the malpractice liability system.

Currently, malpractice claims against a physician are paid, in most cases, by the physician's malpractice insurance carrier. There is some discrimination in the premiums between high and low risk specialities, ${ }^{67}$ and physicians against whom malpractice claims are asserted can experience difficulty in obtaining insurance for as low a premium as other physicians, ${ }^{68}$ but the insurance does accomplish risk spreading. Malpractice insurance, however, is quite expensive. Insurance companies must set aside large reserves to meet claims because of the special nature of medical litigation. Computation of premiums by actuaries is complicated by the fact that many claims are not filed until several years after the policy year, and may not be settled until several years after they are filed-the "long-tail problem." be accumulated during the policy year to meet these future contingencies, a task complicated by inflation. ${ }^{70}$ The insurance company

65. Professor Havighurst and Dr. Tancredi have devised such an approach. Havighurst \&. Tancredi, supra note 10.

66. One estimate states that 15 percent of the malpractice dollar goes to the patient's attorney and 55 percent to the defense attorney and for investigation expenses. Comment, supra note 10, at 426. The malpractice insurer for New York has estimated that 60 cents of the premium dollar go to the injured patient and his attorney. Letter from George $A$. Wright, Jr., Ass't Indemnity Rep., H. F. Wanvig, Inc., to Charles H. Montange, Feb. 5, 1975 (on file with the Yale Law Journal).

67. See Stuing the Doctor, supra note 6, at 78.

68. The experience of California physicians with such problems is presented in Medical Malpractice and the Insurance Industry (Comm. Staff of Cal. Assembly Select Comm. on Med. Malpractice, Memo, Mar. 13, 1974) [hereinafter cited as California Insurance]. For a general discussion, see Kendall \&. Haldi, The Medical Malpractice Insurance Market, in APPENDIX TO REPORT, supra note 10, at 494.

69. California Insurance, supra note 68, at 7.8. See Bird, Malpractice Insurance: $A$ Crisis in Health Care, N.Y. Times, Jan. 19, 1975, at 1, col. 2.

70. The current recession, which has caused the value of insurance reserves to decline, has also made liability insurance less attractive to insurers, see Wall St. J., Jan. 20, 1975, at 1, col. 6, including insurers of physicians for malpractice, see Telephone Interview, 
also charges more because of additional risks due to the small size of the malpractice insurance market, ${ }^{71}$ the "big claim,"72 and the difficulty in predicting the trend in the frequency of claims. ${ }^{73}$ Approximately 25 percent of a physician's malpractice insurance premium consequently is consumed by the maloccurrence insurer. ${ }^{7 \cdot 1}$ An additional estimated 50 percent of the premium is consumed by lawyers in the form of fees for services in medical litigation. ${ }^{75}$

The administrative expense of malpractice insurance and litigation is thus very high under the present negligence system. But if the expense were to remain significant after the implementation of strict liability, then one of the major advantages claimed for strict liability systems generally ${ }^{60}$ would not materialize in the medical care field. The uncertainty of medical care in fact makes continued high expenses likely. There would no longer be litigation over the standard of care, but there is significant potential for litigation over the issue of iatrogenicity. Consequently, lawyers' fees under strict liability may still take a large piece of any plaintiff's pie. Physicians, furthermore, must insure against additional risks under strict liability-namely, the risks of maloccurrences which are not worth avoiding. Added uncertainty over the extent of these risks will probably cause insurance companies to continue to amass large reserves-keeping premiums high. ${ }^{77}$

supra note 5. Arbitration of medical malpractice claims has been suggested as a possible cheaper alternative to present litigation, since arbitration would promote prompt settlements, thus minimizing the need for large reserves due to inflation and future uncertainties. Also, arbitration supposedly would result in lower fees. Interview with Leonard Tomat, supra note 49. See Preliminary Report, supra note 2, at 57; cf. N.Y. Times, Jan. 13, 1974, at 33, col. 2; G. Parrella, supra note 50. Senators Kennedy and Inouye have proposed a bill establishing a national system of arbitration for medical malpractice claims. S. 482, 94th Cong., 1st Sess. (1975), discussed in 121 CoNG. REc. S1142 (daily ed. Jan. 29, 1975).

71. California Insurance, supra note 68 , at 7 .

72. A very small proportion of all claims filed will result in disproportionately large recoveries. Since the small number of "big claims" is unpredictable, actuaries have difficulty calculating coverage formulae. Id.

73. A large increase in frequency of claims occurred in the late 1940's and early 1950's. After a plateau, the frequency has risen dramatically since the early 1960's. Consequently the frequency factor is difficult for an actuary to estimate. Id. at 8 .

74. See, e.g., G. Parrella, supra note 50, at 2.

75. See, e.g., id. Estimates, of course, vary widely. See Comment, supra note 10, at 426 (70 percent to lawyers and investigation fees), 445 (patient receives 16 to 27 percent of total malpractice premium); PReliminary RePORT, supra note 2, at 5-6 (16 to 25 percent of insurance premium goes to patient).

76. See note 61 supra; G. CALABRESI, supra note 16, at 250-55.

77. Telephone Interview with D. John Pecorino, Manager in Marketing Dept, professional liability specialist, Aetna Life \& Casualty Co., Hartford, Conn., Jan. 17, 1975 (notes on file with the Yale Law Journal). Pecorino termed the costs of strict liability "almost impossible" to determine. He suggested that the cost for such coverage would increase. 


\section{Determination of the Final Cost Bearer}

If physicians are able to pass the costs of liability (which includes insurance premiums) to patients, the ultimate risk bearers will be the patients even though initial liability is placed upon the physician. There is evidence that part of the cost of liability is now borne by patients, ${ }^{78}$ although it is unlikely that physicians have sufficient unexercised market power to pass on all the cost of liability. This problem complicates incentives to avoid risks that the current fault system or a proposed strict liability system would supposedly provide. Imposition of strict liability upon physicians who can pass on the costs will produce no economic incentives for physicians to change their conduct. Physicians could more likely pass costs of maloccurrences to patients if patients were receiving health care subsidies from the government, or met medical expenses through health insurance. ${ }^{79}$ The switch to strict liability might then only serve to increase costs to patients. ${ }^{80}$ This is particularly true if high administrative expenses are passed to patients.

\section{Incentives for Research}

Strict liability is often imposed even in situations involving unavoidable risks because the law assumes that such additional liability will cause the liable party to engage in research to discover new methods to avoid the risk. ${ }^{81}$ Thus, unavoidability in and of itself is not grounds for opposing strict liability. But if decisionmakers impose no-fault liability in order to encourage research, such liability should be imposed upon a group which can organize to produce and distribute research.

It is unlikely that practicing physicians can organize an efficient

78. "When a California patient visits a doctor's office now, for instance, it is estimated that as much as $\$ 1.50$ of the amount charged for the visit goes to cover the doctor's malpractice insurance premiums." Preliminary Rerort, supra note 2, at 49; see HEW SEC'Y's REPORT, supra note 9 , at 13 .

79. See Arrow, supra note 15, at 961-64; Pauly, The Economics of Moral Hazarl: Comment, 58 AM. EcoN. REv. 531 (1968); Arrow, The Economics of Moral Hazard: Further Comment, 58 id. 537.

80. The increase in costs to the patient entails a second problem. The patient might then fail to purchase health care when he should, thus increasing the number, and cost, of maloccurrences overall.

An interesting redistributional effect resulting from strict liability is an income transfer from poor victims to rich victims. This occurs if providers can raise prices to cover accident costs. In such a case, part of the price for medical care paid by a poor patient would be directed to compensating rich patients, whose losses from any given maloccurrence might be greater than those of the poor patient. See Oi, The Economics of Product Safety, 4 BeIL J. ECON. \& MAN. ScI. 3 (1973); Oi, The Economics of Product Safety: A Rejoinder, 5 id. 689, 690 (1974).

81. See Calabresi \& Hirschoff, supra note 32, at 1071 . 
market for research innovations useful to themselves as practitioners. ${ }^{82}$ The National Academy of Sciences has stated that "defects of the market mechanism with respect to the allocation of resources toward and among investments in research imply that the market needs to be supplemented, and perhaps, with respect to basic scientific research, entirely replaced by social provision and allocation of resources for the support of scientific research." ${ }^{83}$ Imposition of strict liability is not likely to change these basic market characteristics. Government intervention probably would remain necessary in order to obtain a socially optimal allocation of resources to the acquisition of new knowledge.

\section{Strict Liability: A Reappraisal}

Calabresi-Hirschoff strict liability attempts to increase the likelihood that optimal allocation choices will be made in risky situations by placing liability on the group best equipped to make the choice and carry it out. This approach relies upon private decisionmakers encouraged by market incentives. However, the special nature of medical care complicates the usual analysis of strict liability. Provider uncertainty, the inherent riskiness of medical care, and the difficulty in organizing a market for information and research make it unlikely that strict liability is a panacea for problems generated by medical litigation, especially if such a system is implemented unsystematically through the state courts. ${ }^{84}$

Two central problems at a practical level may be isolated: the unlikelihood of a marked reduction in the very high administrative costs, and the need to ensure that information is generated and shared in an efficient fashion. If strict liability is to be implemented, special attention must be given to these factors.

82. The inadequate devotion of resources to research is a result of external economies which cause a divergence between the private and social benefits of research. Since the private benefits are less, the market underinvests in basic research. E. Mansfield, MicroECONOMICS 430 (1970); Arrow, supra note 15, at 946 n.8; Hearings on Health, Education, and Welfare Regulations for Health Services, 1973, Appendix-Comprehensive HEI Simplification and Reform- "MEGA Proposal" Before the Subcomm. on Health of the Senate Comm. on Labor and Public Welfare, 93d Cong., 1st Sess. 284.85 (1973).

83. National Academy of Sciences, Basic Research and National Goals, Report to the Commitree on Science and Astronautics of the United States House of RepRESENTATIVEs 136 (1965), quoted in E. MANSField, supra note 82, at 430. It has been argued elsewhere that only governmental intervention can achieve the optimal amount of research. See, e.g., Daddario, Science Policy: Relationships Are the Key, DaEdalus, Summer 1974 , at 135 .

84. If a least cost avoider does not exist for many of the maloccurrences in the medical care market, liability may be attributed on grounds other than efficient allocation of resources. Thus, lawmakers may still propose strict liability, or some other type of liability, for distributional or other reasons. 


\section{The Inouye-Kennedy No-Fault Proposal: S. 215}

On January 17, 1975, Senators Inouye and Kennedy proposed a bill, S. $215,^{85}$ to enact optional strict liability for medical maloccurrences. S. 215 demonstrates the possibility of devising a strict liability system which may reduce administrative costs relative to compensation paid to patients, and gather information in useful forms.

The bill proposes a federal no-fault medical maloccurrence insurance fund ${ }^{86}$ supported entirely by premiums charged to health care providers $^{87}$ who elect to participate. ${ }^{88} \mathrm{~S}$. 215 also would provide federal malpractice insurance for traditional tort lawsuits. ${ }^{89}$ Patients of providers who participate in the fund may bring a claim against their provider in either the federal no-fault system (with claims presented initially to the Secretary of HEW) or in the traditional state negligence systems, but not both. ${ }^{90}$

The bill provides for no-fault ${ }^{01}$ compensation 02 for "loss from any injury suffered as a result of health care services provided by an insured to [any] beneficiary ...." ${ }^{33}$ An injury "means physical harm, bodily impairment, disfigurement, or delay in recovery." " $[\mathrm{A}] \mathrm{n}$ in-

85. S. 215, 94th Cong., 1st Sess. (1975); see 121 Cong. Rec. S413-21 (daily ed. Jan. 17, 1975). In addition Senator Nelson has introduced S. 188, a bill to authorize the Secretary of HEW to establish a medical malpractice reinsurance program, and to conduct experiments and studies on medical malpractice. 121 CoNc. REC. S292 (daily ed. Jan. 16, 1975). See also H.R. 1378, 94th Cong., lst Sess. (1975).

86. S. 215, 94th Cong., 1st Sess. \$ 1702(a) (1975).

87. Id. $\S 1703$. The bill is not clear as to whether the fund is to develop a reserve to meet claims in the future arising out of mishaps in a given year, thus acting as a true insurer, or is simply to spread the cost of all settled claims among providers in the year the claims were settled regardless of the year in which they originated.

88. 121 CoNG. REc. S414, col. 2 (daily ed. Jan. 17, 1975) (remarks of Senator Inouye). Providers, in order to participate in the no-fault system, must submit to national licensing requirements (compare S. 215, 94th Cong., 1st Sess. $\$ 1704$ (a) (1975) with id. $\$ 1731$ ) and certain review procedures. $I d$. $\$ \S 1704(\mathrm{~b})$, (c). If an undue number of claims are filed against a provider, an investigation shall be ordered. Id. \$ 1707(b). Federal coverage can be terminated if the provider is found to give patients harmful or inadequate services. Id. $\$ 1706(\mathrm{~b})(4)$. This latter provision may punish patients more than the deficient provider and seems mainly designed to protect the insurance fund against claims. A better approach would entail disciplinary action against the provider rather than taking insurance protection from the patients.

89. S. 215, 94th Cong., 1st Sess. $\$ 1708$ (1975).

90. Id. $\$ 1717$. Claims under the federal no-fault system would be presented to the Secretary of HEW. Id. $\$ 1715(\mathrm{a})$. Within 60 days of the filing of a claim, the Secretary must make findings of fact and a decision of the claimant's rights. The claimant is entitled to a hearing if he so requests. The Secretary may affirm, modify, or reverse his findings or decision based on evidence adduced at the hearing. Id. "The Secretary's decision may be appealed to the federal district courts. Id. $\$ \$ 1715$ (a)(2), (d). Decisions of the district courts are to be reviewable as any other civil action. Id. $\$ 1715$ (d).

91. See id. $\$ \S 1701(c)(2), 1711,1714,1721(10)$.

92. Compensation is limited to no more than $\$ 2,000$ per month counting other sources of continuing income for economic loss, and $\$ 2,000$ per month for noneconomic loss including pain and suffering. Id. $\$ 1713($ a). No-fault benefits are payable monthly as loss accrues. Id. $\$ 1714(\mathrm{~b})$.

93. Id. \& 1711(a).

94. Id. $\$ 1721(7)$. 
jury 'results' from the provision of health care services when it is more probably associated in whole or in part with the provision of such services than with the condition for which such services were provided." 95 "Health care services" include "the rendering, as well as the omission, of any care, treatment, or services . . . ."00

The broad definition of compensable events will likely result in considerable litigation over iatrogenicity, but the bill does have other provisions which offer some hope of reduced litigation costs. S. 215 abolishes contingency fees for attorneys for work in the no-fault system. ${ }^{97}$ Attorney's compensation is limited to "reasonable" fees for services rendered, ${ }^{98}$ whether or not the patient is successful with his no-fault claim. The proportion of damages going to patients, relative to the no-fault insurance premium, may therefore be expected to be larger than under the present system. The bill presumably would result in administrative savings if special hearing officers developed expertise in ascertaining when maloccurrences are iatrogenic. ${ }^{90}$

S. 215 provides a good framework for the compilation of information regarding maloccurrences, ${ }^{100}$ an invaluable basis on which to

95. Id. $\$ 1721(8)$. A problem develops if the maloccurrence is compensable if it is only "in part" therapy-induced. If this means that federal no-fault will compensate for the entire illness because the patient suffers an iatrogenic maloccurrence aggravating the illness, then the health care provider is moved toward the position of general health insurer. Congress, in that case, could properly consider requiring provider premiums to meet only the portion of the expense of the fund allocable to iatrogenic disorders. The remainder could be paid directly through national health insurance or some other source. 96. Id. \& 1721(11).

97. Id. $\$ 1726(\mathrm{a})$. This provision might give rise to some abuses, since the no-fault system is optional. Attorneys anxious for large contingency fees might encourage traditional negligence lawsuits in the state courts for cases in which the negligence is clear and damages large, but bring claims of lesser value or claims in which the provider was not at fault under the Inouye-Kennedy proposal. Thought might therefore be given to restricting use of the contingency fee malpractice cases brought in state courts so the federal no-fault plan is not disadvantaged. A second problem develops if the Secretary adopts restrictive procedures, provides insufficient compensation to patients, or insufficiently compensates attorneys who represent patients, in order to hold down the costs of the Inouye-Kennedy proposal. If the Secretary fails to compensate at least as adequately as the negligence system, attorneys may consistently advise their clients to seek traditional tort remedies, at least in "surer" cases.

98. Id.

99. Some elements of potential negligence litigation remain, even under the InouyeKennedy no-fault proposal. A provider must inform his patient of a possible no-fault claim within 30 days after the provider knew or "reasonably should have known" of the claim's feasibility. Id. $\$ 1705(c)(2)$. If the provider fails to inform, he is personally liable. Id. Given the difficulty in defining the scope of compensable events, it is conceivable that there could be considerable controversy over what the physician or hospital reasonably should have known. Consequently, there may be a number of providers personally liable in the no-fault system. This possibility may deter providers from participating in the system. The bill is commendable in seeking to pressure providers, the parties with the best access to the information concerning iatrogenicity, to disclose facts even though the disclosure is contrary to the provider's interests. The proposal may go, however, too far. Perhaps it should be amended to place some limits on providers' liability for failure to disclose.

100. The Secretary must report all claims to relevant state personncl. Id. $\$ 1707(a)(1)$. In case of an unusually high number of claims, the Secretary shall investigate the provider involved. Id. \$ $1707(\mathrm{~b})$. 
evaluate the costs and benefits of various treatments, and to evaluate possibly deficient providers. Areas requiring research could more readily be identified. A strict liability system implemented through the state courts would not provide this important information in such an efficient framework. Certainly the present negligence system does not.

Enactment of some form of S. 215 would provide a useful test of the feasibility of strict liability in the medical care market. Optional no-fault might provide a useful adjunct to an arsenal of measures aimed at achieving optimal medical care at minimal expense. An alternative approach in the arsenal involves explicit choices by collective decisionmakers to prohibit certain activities.

\section{B. Collective Deterrence}

\section{Collective Prohibitions as a Means of Providing Information}

Liability rules may be treated as part of an information processing system. ${ }^{101}$ For example, Calabresi-Hirschoff strict liability may be viewed as consumer delegation of part of the information processing task to the producer (assuming the latter is the least cost avoider) as an agent. But in the medical-care market, the producer-the physicianis not necessarily generally possessed of efficient means of acquiring all the relevant knowledge to act as an optimal information processing system. ${ }^{102}$ The best such system in the medical-care industry might include explicit prohibitions on certain risky activities. ${ }^{103}$ For example, prohibition of the use of thalidomide is seen, in a sense, as the cheapest way to inform physicians and patients of the drug's dangerous properties. ${ }^{104}$ However, reliance solely on prohibitions of certain procedures would either reach only the grossest instances of inappropriate practices, or would prevent individualized treatment desirable to reflect special circumstances presented by the complexities of particular cases. Thus, a scheme of general rules should be flexible enough to recognize appropriate exceptions.

101. Goldberg, The Economics of Product Safety and Imperfect Information, 5 BELL J. Econ. \& Man. ScI. 683, 685 (1974).

102. See Murnaghan, supra note 18, at 605 . One means of improving the functioning of health care providers is the use of patient-care protocols. Grimm, Shimoni, Harlan \& Estes, Evaluation of Patient-Care Protocol Use by Various Providers, 292 NEw ENG. J. MED. 507 (1975).

103. See Goldberg, supra note 101.

104. Cf. G. CALABRESI, supra note 16, at 103-07. 


\section{The PSRO Amendment: A Missed Opportunity}

Enacted in 1972, the Professional Standards Review Organization (PSRO) Amendment ${ }^{\mathbf{1 0 5}}$ to the Medicare and Medicaid provisions of the Social Security Act represents a variation on the collective deterrence model. The PSRO Amendment was passed primarily to limit the costs of federal health care programs by eliminating unnecessary provision of medical services. ${ }^{106}$ It requires the establishment, in cooperation with the medical profession, ${ }^{107}$ of Professional Standards Review Organizations in regions throughout the country, to set standards for medical services provided to Medicare and Medicaid patients. Congress repeatedly asserted that these criteria should be based on customary standards ${ }^{108}$ as established by local physicians. ${ }^{109}$

Providers are given three incentives to abide by the standards set by a PSRO. A PSRO may recommend that a noncomplying physician be suspended from eligibility for program reimbursements for Medicare or Medicaid medical services. ${ }^{110}$ Alternatively, the practitioner may be required to pay back to the government up to $\$ 5000$ for disapproved services. ${ }^{111}$ The critical feature of the PSRO Amendment,

105. 42 U.S.C. $\$ 1320 \cdot c$ (Supp. II, 1972). For a good discussion, see Note, Federally Imposed Self-Regulation of Medical Practice: $A$ Critique of the Professional Standards Review Organization, 42 GEO. WASH. L. Rev. 822 (1974). See generally Comment, PSRO: Malpractice Liability and the Impact of the Civil Immunity Clause, 62 GEO. L.J. 1499 (1974).

106. See Note, supra note 105 , at 825 . The problem of rendition of unnecessary treatment still continues. Cerra, Program Here Finds $28 \%$ of Surgery Unnecessary, N.Y. Times, Dec. 15, 1974, at 1, col. 6; McCarthy \& Widmer, Effects of Screening by Consultants on Recommended Elective Surgical Procedures, 291 New ENG. J. MED. 1331 (1974); cf. Bloom \& Peterson, Patient Needs and Medical-Care Planning, 290 id. 1171 (\$3 million annually could be saved through economies of scale and better admission criteria in coronary care units in Massachusetts); Hearings on Health Care Crisis in America, 1971, Before the Subcomm. on Health of the Senate Comm. on Labor and Public Welfare, 92d Cong., lst Sess., pt. 3, at 394-95 (1971).

This concern has manifested itself in efforts to control expenditures for hospitals as well. See N.Y. Times, Dec. 16, 1974, at 27, col. 4; 32 Cons. Q.W. RE1. 3222-23 (1974), discussing National Health Planning and Resources Development Act of 1974, Pub. L. No. 93-641, 88 Stat. 2225 (to revise and extend federal health planning programs).

107. The American Medical Association faced a near revolt of its constituents in agreeing to cooperate in implementation of the PSRO legislation. After ferocious opposition, see, e.g., Spivak, "Heal Thyself..." Medical-Care Review Stirs a Fiery Debate Among U.S. Doctors, Wall St. J., June 24,1974 , at 1 , col. 1 , the A.M.A. decided to cooperate with the federal government. See Kramer, AMA Eases Opposition to Plan to Monitor Care of Medicaid and Medicare Patients, Wall St. J., June 27, 1974, at 8, col. I.

The American Medical Association has filed suit to block the hospital utilization review aspects of the PSRO Amendment. Delaney, A.M.A. Suing U.S. over Peer Review, N.Y. Times, Feb. 21, 1975, at 1, col. 8 .

108. See, e.g., 42 U.S.C. $\$ \$ 1320 \mathrm{c}-4(\mathrm{a})(1)(\mathrm{B}),-5(\mathrm{a}),-9(\mathrm{a})(\mathrm{l})(\mathrm{B}) \&(\mathrm{D}),-9(\mathrm{a})(2)(\mathrm{A})$ (Supp. II, 1972).

109. Surprisingly, the Amendment seems to require that the standards be set and monitored by local experts, contrary to the developments in state litigation which are toward national standards or even away from customary conduct as an absolute defense at all. See p. 1163 infra. See 42 U.S.C. $\$ \$ 1320 c-4(\mathrm{~b})(1)$, (d)(1) (Supp. II, 1972).

110. Id. $\$ 1920 \mathrm{c}-9(\mathrm{~b})(1)$.

111. Id. \$1320c-9(b)(3). 
however, is a purported grant of malpractice immunity to a physician or other provider for "any action taken by him in compliance with or reliance upon professionally developed norms of care and treatment applied by a [PSRO] . ..." The immunity applies if the physician or provider "exercised due care in ... actions taken in compliance [with PSRO standards]." 112 This provision could be interpreted as a flat grant of immunity if PSRO standards are followed, or as a rebuttable presumption that a physician acted nonnegligently if he abided by the standards. ${ }^{113}$ If the PSRO Amendment is interpreted as an immunity provision, the federal government will in effect have legislated a mandatory custom defense. Caspar Weinberger, Secretary of HEW, apparently supports the absolute immunity interpretation: "I would like to see states adopt the rule that physicians and others who adhere to standards of care adopted by local PSRO's will be able to assert this as a real defense to a malpractice suit, and thus reduce materially the cost of unnecessary defensive medical practice."114 The Medical Society of the State of New York is apparently advocating such an approach. ${ }^{115}$ But there is nothing in the present PSRO law which will prompt PSRO's to adopt "necessary" and reject "unnecessary" treatments-the law simply fails to indicate what optimal treatment is other than customary practice. ${ }^{116}$

Congress should have required that a PSRO be guided in setting its standards by whether a particular treatment results in benefits in excess of costs; PSRO's could then have served to alleviate provider uncertainty. ${ }^{117}$ However, there is no mechanism encouraging, or even

112. Id. $\$ 1320 c-16(c)$.

113. Note, supra note 105 , at $838-39$.

114. Malpractice Crisis Warned, Am. Med. News, Jan. 6, 1975, at 9, col. 4.

115. See N.Y. Times, Jan. 13, 1975, at 33, col. 1 .

116. Further, experience with self-regulation by health care providers suggests the conclusion that some alternative means of policing medical decisionmaking is necessary in order to assure that minimal standards are established. See, e.g., Preliminary Report, supra note 2, at 50-56; Gentry v. Department of Professional \& Öccup. Regs., 293 So. $2 d$ 95, 97 (Fla. App. 1974) (professional licensing board prohibited from suspending practitioner's license for mere negligence); Hearings, supra note 106, pt. 2, at 227-28. General standards should not protect a provider who fails to tailor his services to an individual patient with an unusual medical problem. See Note, supra note 105, at 841.42.

The defective PSRO Amendment is important in light of calls for the establishment of some variety of national health insurance. See Lyons, A Health-Care Bill? Prognosis is Maybe, N.Y. Times, Jan. $12,1975, \S 5$, at 5 , col. 1 . It is possible that a rational health insurance plan might incorporate organizations with powers modeled after those cstab. lished by the PSRO Amendment. S. 215 also refers to compliance with PSRO Amendment requirements. See S. 215, 94th Cong., 1st Sess. \$§ 1704(a), (c)(1).

117. See Anderson, PSRO as Educational Process, 290 NEw ENG. J. Med. 1322-23 (1974); Colcock, PSRO's, 290 id. 1318; Welch, supra note 7, at 1319; cf. Buck \& White, Peer Re. view: Impact of a System Based on Billing Claims, 291 id. 877.

Lawmakers could also improve the sharing of information by encouraging access of patients to their medical records. See Shenkin \&. Warner, Giving the Patient His Medical Record: A Proposal to Improve the System, 289 NEw ENG. J. MED. 688 (1973); A. Golodetz, J. Ruess \& R. Milhous, The Right to Know: Giving the Patient His Medical Record (Paper presented to Nov. 1974 meeting of the Am. Cong. of Rehabilitation Med. and the 
enabling, the PSRO's to undertake this type of cost-benefit research. ${ }^{118}$ The emphasis is upon existing regional custom. The Amendment unwisely runs contrary to an incipient movement in the states, exemplified in Helling $v$. Carey, ${ }^{119}$ to cut back on the custom defense. Congress missed an important opportunity, but the PSRO mandate could yet be changed so that the organizations are induced to set standards on the basis of systematic studies, ${ }^{120}$ rather than simply enshrining the local customary practice-whether or not that practice best serves patients' interests.

\section{Conclusion}

Minimizing the costs of medical maloccurrences, the costs of maloccurrence avoidance, and administrative costs in medical litigation presents difficulties due to the lack of information in the medical care market. No liability system is without problems, but strict liability is far from a panacea. A dramatic savings in administrative costs is less likely to materialize with medical care strict liability than with strict liability in other tort areas, because of the difficulties in determining iatrogenicity. Nonetheless, legislatures might consider systems of strict liability, either limited in scope or optional like S. 215, as supplements to the present negligence framework. Important improvement could also be achieved within the negligence framework: for example, courts should continue to cut back on the custom defense where existing medical practice is not providing optimal care to patients. Finally, to the extent that lawmakers rely on collective deterrence, they should avoid unthinking adoption of existing customary medical care. They should instead enact standards derived from systematic cost-benefit analysis.

Am. Acad. of Physical Med.); Rosenberg, Informed Consent-An Appraisal of Patients' Reactions, Hosp. MED. STAFF, July 1974, at 12; Cannell v. Medical \& Surg. Clinics, S.C., 315 N.E.2d 278 (IIl. App. 1974).

118. The National Professional Standards Review Council may make studies on which to base recommendations. 42 U.S.C. $\$ 1320 c-12(\mathrm{e})(4)$ (Supp. II, 1974). However, there is no instruction to direct the studies toward areas of medicine in which practitioners would benefit from research. For another critique of PSRO's, see Willett, PSRO Today: $A$ Lawyer's Assessment, 292 NEw ENG. J. MED. 340 (1975); Simmons, PSRO Today: The Program's Viewpoint, 292 id. 365.

119. 83 Wash. 2d 514, 519 P.2d 981 (1974); see note 44 supra.

120. Such studies are possible and have been done for some medical procedures. E.g., Mass. Dep't of Public Health, Cost-Benefit Analysis of Newborn Screening for Metabolic Disorders, 291 NEw ENG. J. MED. 1414 (1974) (net savings if PKU test is given); McCarthy \& Widmer, Effects of Screening by Consultants on Recommended Elective Surgical Pro. cedures, 291 id. 1331 (net savings if screening utilized); Sagel, Evens, Forest \& Bramson, Efficacy of Routing Screening and Lateral Chest Radiographs in a Hospital-Based Population, 291 id. 1001. Cf. Logerfo, Cost-Benefits in PSRO Law, 292 id. 53; Welch, Cost-Benefits in PSRO Law, 292 id. 54; Katz, A Probability Graph Describing the Predictive Value of a Highly Sensitive Diagnostic Test, 291 id. 1115; Bloom \& Peterson, Patient Needs and Medical-Care Planning, 290 id. 1171. 